\title{
Food web components, and physical and chemical properties of Baltic Sea ice
}

\author{
Hermanni Kaartokallio*
}

Finnish Institute of Marine Research, PO Box 33, 00931 Helsinki, Finland, and Tvärminne Zoological Station, 10900 Hanko, Finland

\begin{abstract}
Fast ice and underlying water of the northern Baltic Sea were sampled at 1 wk intervals during winter 2000 in a coastal location in SW Finland. To investigate seasonal succession and interactions inside the food web and between the food web and physical and chemical properties of the ice, several biological (chlorophyll $a$, abundance of bacteria, flagellates and ciliates, bacterial cell volume and leucine incorporation, POC), chemical (total and dissolved nutrients) and physical (salinity, temperature) parameters were measured. The first ice-algae bloom with chlorophyll a (chl a) concentrations of up to $18.5 \mathrm{\mu g} \mathrm{l}^{-1}$ occurred in mid-January, followed by the main ice-algae bloom in March and a heterotrophic postbloom situation shortly before the ice deteriorated in April. The iceorganism assemblage was autotrophy-dominated; during the entire ice-covered period, ice algae formed on average $82 \pm 10 \%$ (mean \pm SD) of the organism biomass. The largest heterotrophic groups by biomass were bacteria $(16.7 \pm 9.4 \%)$, ciliates and metazoans $(4.4 \pm 2.7$ and $4.4 \pm 4.8 \%$, respectively). The ice food-web was characterized by the importance of ice bacteria and the presence of a potential microbial loop (bacterial secondary production accounting for a mean of $27.1 \pm 19.3 \mu \mathrm{mol} C$ $\mathrm{m}^{-2} \mathrm{~d}^{-1}$ ), grazing control on bacteria and flagellates, and also possible 'shortcuts' such as ciliate grazing on bacteria and metazoan herbivory. An ice-sheet warming event in February clearly affected the physical and chemical properties of the ice as well as the structure and function of iceorganism assemblages. Ice organisms probably controlled dissolved nutrient concentrations inside the ice by uptake and regeneration.
\end{abstract}

KEY WORDS: Sea ice $\cdot$ Bacterial production $\cdot$ Microbial food web $\cdot$ Nutrients

Resale or republication not permitted without written consent of the publisher

\section{INTRODUCTION}

Sea ice is an important element of the northern Baltic Sea ecosystem. The probability of annual ice occurrence on the coasts of Finland is $>90 \%$ (see Fig. 1) and ice coverage lasts for 2 to 6 mo (mean 3 mo) on the SW coast of Finland (Mälkki \& Tamsalu 1985). Despite the brackish nature of the Baltic Sea, its ice is structurally similar to polar sea ice and contains an internal brinechannel system (Leppäranta et al. 1998). Due to low water salinity, brine volumes in the Baltic Sea are rather small compared with those found in polar sea ice (e.g. Meiners et al. 2002). However, high diversity of sea ice-associated microbes also occurs in interior habitats of Baltic sea ice (Norrman \& Andersson 1994, Ikävalko \& Thomsen 1997, Haecky et al. 1998, Meiners et al. 2002).
Biomass accumulation of sea ice algae communities generally follows the seasonal trend in solar radiation, beginning during the winter/spring transition and lasting until the onset of ice melt (Cota et al. 1991, Norrman \& Andersson 1994, Haecky \& Andersson 1999). The significance of heterotrophic processes usually increases in late-bloom and postbloom situations late in the sea ice season (e.g. Stoecker et al. 1993, Vezina et al. 1997). A successional sequence beginning with a low-productive winter stage and followed by an algal bloom and a heterotrophy-dominated postbloom situation occurs in the Gulf of Bothnia, the northernmost part of the Baltic Sea (Haecky \& Andersson 1999).

Concentrations of dissolved organic carbon (DOC) in the sea ice environment are generally significantly higher than those of surface waters (Thomas \& Papadimitriou 2003). DOC is thought to originate from 
ice-algae exudation, protozoan and metazoan grazing, and degradation of particulate organic matter (POM; Thomas et al. 1995, Smith et al. 1997). Recycling of DOC via the microbial loop is considered to be a major link between primary and secondary producers (Gradinger et al. 1992). The significance of micrograzer herbivory and the microbial loop is assumed to increase with decreasing algal productivity (Laurion et al. 1995, Sime-Ngando et al. 1997). Different 'shortcuts' in energy and matter flow are typical for microbial food webs inside the sea ice. These include ciliate and flagellate herbivory, ciliate grazing on bacteria and direct utilization of DOC by heterotrophic flagellates (HFLs; Sherr 1988, Gradinger et al. 1992, Stoecker et al. 1993, Laurion et al. 1995, Sime-Ngando et al. 1997, Vezina et al. 1997, Haecky \& Andersson 1999).

Previous studies in polar areas (e.g. Gradinger et al. 1992, Fritsen et al. 1994, Hudier \& Ingram 1994) and experimental systems (Krembs et al. 2000, 2001) suggest a close coupling between physical and chemical properties of the ice and biological processes occurring in the ice. The temperature in thin ice changes rapidly along with air temperature (Krembs et al. 2001, Granskog et al. 2003) and variables that are dependent on ice temperature, such as brine salinity, concentrations of dissolved constituents and available surfaces inside the brine-channel system, can fluctuate over short timescales. In addition, temperature-dependent changes in brine-channel morphology and brine transport processes may be crucial factors shaping the ice-organism community structure and functioning (Gradinger et al. 1992, Krembs et al. 2000). Reported measured brine salinity values from Baltic sea ice range between 6 and 30 psu (Ikävalko \& Thomsen 1997, Mock et al. 1997, Kaartokallio 2001) and brine salinity can fluctuate rapidly (Granskog et al. 2003) as ice temperature changes. Brine salinity is lower than in polar seas; the reported median value for calculated brine salinity of Baltic sea ice is 10.1 (Meiners et al. 2002) and for measured brine salinity 7.9 psu (recalculated from data presented in Kaartokallio 2001).

The main nutrient supply in the internal habitat of the sea ice is the initial nutrient entrapment and, in older sea ice, nutrient transport connected with brine movements (Dieckmann et al. 1991, Golden et al. 1998). As the ice season advances, another important inorganic nutrient source is regenerative supply inside the sea ice (Cota et al. 1991). Ice bacteria degrade POM (Helmke \& Weyland 1995) and regenerate nutrients. Phagotrophic protists are also likely to be important nutrient regenerators in the sea ice environment (Stoecker et al. 1993).

In the present study, an attempt is made to describe the dynamic interactions occurring between the micro- bial food web of the Baltic sea ice and its regulative factors as constrained by the physical and chemical properties of the ice, using a high-resolution timeseries dataset collected at a coastal location on the SW coast of Finland.

\section{MATERIALS AND METHODS}

Study site and sampling. The time-series dataset was collected during the mild winter of 2000 in the semi-enclosed, shallow Santala Bay, a coastal location in SW Finland (Fig. 1). Sampling, including ice and under-ice water samples, was performed at $1 \mathrm{wk}$ intervals throughout the entire ice season from January to April. In addition, open-water samples were taken before ice formation in December and after ice breakup in April. Sampled sea ice was land-fast level ice with a maximum thickness of $27 \mathrm{~cm}$. Snow cover was generally absent during the study period. The first 4 samplings in January were near the shoreline, where freezing began. The samples were later taken from the middle of the bay, a few hundred meters away from the first site. The water depth at the first site was $1 \mathrm{~m}$ and at the second site $6 \mathrm{~m}$. The ice cores were drilled with a Kovacs CRREL-type power core auger. The ice temperature was measured from the ice core at $5 \mathrm{~cm}$ intervals immediately after drilling using a Testo 720 electrical thermometer, the cores were cut into $5 \mathrm{~cm}$ sections with a handsaw and placed in clean plastic

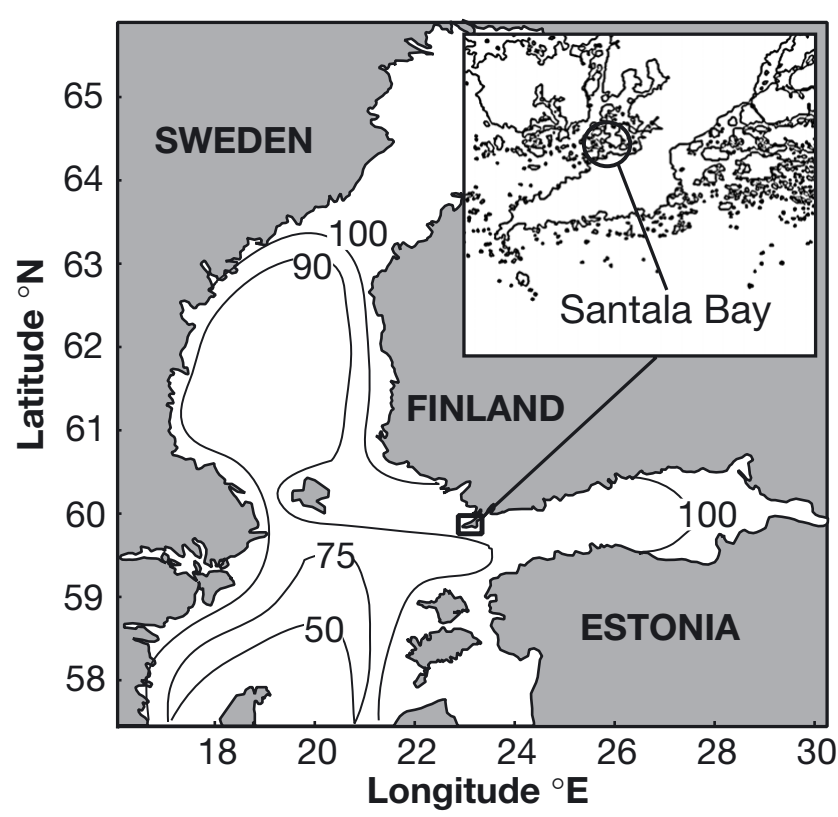

Fig. 1. Northern Baltic Sea, showing sampling location. Contour lines denote percentage of annual ice occurrence probability (contours redrawn from Mälkki \& Tamsalu 1985) 
containers. Under-ice water samples were obtained from 0.2 to $0.3 \mathrm{~m}$ and from 14 March onward at $5 \mathrm{~m}$ using a 11 Ruttner water sampler. All samples were kept dark and cold and transported to the laboratory after collection. The first ice core was immediately subsampled in the laboratory for bacterial secondary production measurements, and then thawed along with the second core in a cold room at $+5^{\circ} \mathrm{C}$ for 24 to $38 \mathrm{~h}$. Direct melting was used, as methodological tests in the study area showed no difference in primary productivity and chlorophyll a ( $\mathrm{chl}$ a) recovery between filtered seawater-buffered melting and direct melting (data not shown). The median for individual brine salinity values (calculated according to Assur 1958) over the entire study period was $4.8 \mathrm{psu}$ and for thawed ice 0.4 psu. Garrison \& Buck (1986) showed that a salinity change of less than 7 psu during melting significantly improves organism recovery. The suitability of direct melting for Baltic sea ice samples is most likely due to the generally low salinity decrease during melting in comparison to polar sea ice. Direct melting has also been previously used in several Baltic sea ice studies (Norrman \& Andersson 1994, Haecky et al. 1998, Haecky \& Andersson 1999, Kaartokallio 2001). After thawing, the samples were mixed carefully and subsampled for further analyses. Precipitation samples were obtained at 2 wk intervals in February and March, using a fallout collector $(\varnothing 20 \mathrm{~cm})$ placed on ice at $2 \mathrm{~m}$ height near the sampling field. Small-scale spatial variability in measured parameters was investigated on 14 March by taking 3 additional ice cores 1, 2 and $3 \mathrm{~m}$ away from the actual sampling point. From these cores, one $5 \mathrm{~cm}$ ice section was retrieved (depth 6 to $11 \mathrm{~cm}$ from ice surface) and processed along with the other samples.

Physicochemical parameters and chlorophyll a. Salinity was measured for all samples (thawed icecore sections and water) using a YSI (Yellow Springs Instrument) 63 temperature-conductivity-pH meter, calibrated with YSI standard solutions. The concentrations of dissolved inorganic nutrients $\left(\mathrm{PO}_{4}{ }^{3-}-\mathrm{P}, \mathrm{NH}_{4}{ }^{+}-\mathrm{N}\right.$, $\mathrm{NO}_{2}{ }^{-}-\mathrm{N}$ and $\left.\mathrm{NO}_{3}{ }^{-}-\mathrm{N}\right)$ were either determined manually immediately after ice thawing, or frozen and analyzed 2 to 3 mo later using a Lachat QC 8000 autoanalyzer. The $\mathrm{NH}_{4}{ }^{+}-\mathrm{N}$ was always determined manually immediately after thawing. The subsamples for total nitrogen (TN) and total phosphorus (TP) determination were stored frozen in $40 \mathrm{ml}$ acid-washed glass bottles and analyzed 3 mo later using a Skalar 5100 autoanalyzer. Standard seawater procedures (Grasshoff et al. 1983) were used for all nutrient determinations. To reveal salinity-independent changes in concentrations of dissolved nutrients, these were normalized to the salinity of the underlying water at the time of initial ice for-mation by the equation $\mathrm{C}_{\text {norm }}=\mathrm{S}_{\text {water }} / \mathrm{S}_{\text {actual }} \times$
$\mathrm{C}_{\text {actual, }}$ where $\mathrm{C}$ refers to concentration and $\mathrm{S}$ to salinity. For determination of chl a, $50 \mathrm{ml}$ aliquots of sample water (thawed ice, water) were filtered through $25 \mathrm{~mm}$ Whatman GF/F filters. The filters were placed in $10 \mathrm{ml}$ $94 \%$ v/v ethanol and chl a was extracted at room temperature in the dark for $24 \mathrm{~h}$. The extract was filtered through a GF/F filter and fluorescence was measured with a Perkin-Elmer LS-2B fluorometer, calibrated with pure chl a. The chl a concentrations were calculated according to HELCOM (1988). For the measurement of particulate organic carbon (POC) and particulate organic nitrogen (PON) $50 \mathrm{ml}$ aliquots of thawed ice or water samples were filtered through a precombusted $\left(450^{\circ} \mathrm{C}, 5 \mathrm{~h}\right) \mathrm{GF} / \mathrm{F}$ filters $(\varnothing 13 \mathrm{~mm})$. The dried filters were stored in acid-washed Eppendorf tubes for 2 to 3 mo and analyzed using a LECO 900 CHN analyzer. DON was estimated by difference between measured $\mathrm{N}$ pools and calculated as DON = $\mathrm{TN}$ - DIN - PON, assuming that no intracellular N was lost during filtration and $100 \%$ conversion efficiency in TN measurement.

Total bacterial number and biovolume. Subsamples of $20 \mathrm{ml}$ were taken from the thawed ice and water samples and fixed with $25 \%$ electron microscopygrade glutaraldehyde (final concentration $1 \%$ ). Prior to counting, 5 to $10 \mathrm{ml}$ of each sample were filtered onto a black $0.2 \mu \mathrm{m}$ polycarbonate filter (Osmonics) and stained for $5 \mathrm{~min}$ with $0.015 \%$ acridine orange solution. Total bacterial numbers (TBN) were counted using a Leitz Aristoplan epifluorescence microscope equipped with an I3 filter and PL Fluotar $100 \times 12.5 / 20$ oil-immersion objective. The TBN was calculated from at least 200 cells recorded in a minimum of 20 fields in a New Porton E11 counting grid. The bacterial cell volume (BVOL) was determined with image-analysis (Massana et al. 1997). At least 200 bacteria were recorded from each filter using a Photometrics CH250/A charged-couple device camera connected to a Leitz Aristoplan epifluorescence microscope and PMIS image-aqcuisition software. The digital images obtained were analyzed with National Instruments LabView-based LabMicrobe software. The bacterial biomass was calculated using empirically derived mean cell volumes and a carbon conversion factor of

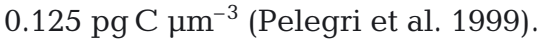

Bacterial secondary production. Bacterial production was measured using a modification of the ${ }^{14} \mathrm{C}$ leucine incorporation method (Kirchman et al. 1985). Production was measured immediately after sample collection and all work was done in a cold room at $+5^{\circ} \mathrm{C}$. Each intact $5 \mathrm{~cm}$ ice-core section was crushed using a spike and electrical ice-cube crusher. Approximately $10 \mathrm{ml}$ of crushed ice were placed in a scintillation vial and weighed with a Sartorius 1413 laboratory balance. The ice density was determined individually 
from each ice-core section by immersing a weighed ice piece in a measuring glass. To better simulate brinepocket salinity and ensure even distribution of labelled substrate, 2 to $4 \mathrm{ml}$ of $2 \times$ concentrated (evaporation) filtered $(0.2 \mu \mathrm{m})$ seawater from sampling area were added to the scintillation vials. The samples were subsequently amended with L-[U- $\left.{ }^{14} \mathrm{C}\right]$ leucine (Amersham) diluted with carrier leucine in a proportion of 1:5. The final leucine concentrations were 200 to $500 \mathrm{nmol}$ $\mathrm{l}^{-1}$ for under-ice water samples and 900 to $1000 \mathrm{nmol}$ $\mathrm{l}^{-1}$ for ice samples. The added leucine concentrations were slightly above the saturation level. Samples were incubated in the dark at $-0.2^{\circ} \mathrm{C}$ in a LMS 305 cooled incubator for 16 to $20 \mathrm{~h}$, incubation was stopped by addition of formaldehyde, and the samples were processed using the standard cold-trichloroacetic acid (TCA) extraction procedure. A Wallac WinSpectral 1414 counter and InstaGel (Perkin-Elmer) cocktail were used in scintillation counting. An incorporation kinetics experiment was conducted to ensure that incorporation was linear over a $20 \mathrm{~h}$ period. The leucine incorporation was corrected for actual ice volume using ice density and sample weight. Bacterial carbon production was calculated using the conversion factors of Bjørnsen \& Kuparinen (1991). To allow comparison to other parameters, leucine incorporation and bacterial production values are presented per melted ice volume.

Abundance of flagellates, ciliates and metazoans. Autotrophic flagellates (AFL) and HFL were counted with the same epifluorescence microscopy setup as bacteria, $10 \mathrm{ml}$ of each sample was stained using $0.033 \%$ proflavine and filtered onto black $0.2 \mu \mathrm{m}$ polycarbonate filters. Flagellates were enumerated, differentiated as auto- and heterotrophic, and divided into 3 size classes, $<5,5$ to 20 and $>20 \mu \mathrm{m}$. The flagellate biovolume was calculated using cell volumes of 50, 800 and $2000 \mu^{3}$, respectively, for the 3 size classes (Kuuppo 1994). The abundance of ciliates and metazoans (rotifers, copepods) present in ice during all 4 sampling occasions in March was calculated from Lugol-fixed $50 \mathrm{ml}$ samples by inverted light microscopy using a Leica inverted microscope and Utermöhl counting technique (Utermöhl 1958). For counting, $50 \mathrm{ml}$ of sample water was settled for $>12 \mathrm{~h}$ and counted with phase-contrast illumination using 125 to $500 \times$ magnifications. The ciliate biovolumes were calculated using species-specific biovolumes (K. Kivi unpubl.). The flagellate and ciliate biovolumes were converted to biomass values using the same carbonconversion factor as for bacteria. The presence of meiofauna (e.g. nematodes) in sea ice was also investigated by sieving the sample water left from other analyses through a $40 \mu \mathrm{m}$ sieve and counting all the organisms under a Wild M8 stereomicroscope. Organisms captured on sieves were mainly rotifers, and from these data a semiquantitative estimate (organisms $>40 \mu \mathrm{m}$ ) for the abundance of metazooplankton could be obtained over the entire study period.

\section{RESULTS}

\section{Weather conditions, salinity, temperature}

During January, the ice cover was limited to proximity to the shoreline and, due to warm weather, did not extend. New ice formed in the middle of the bay in late January, and the sampling point was moved; at the first mid-bay sampling (25 January) ice thickness was $13 \mathrm{~cm}$, increasing to a maximum of $27 \mathrm{~cm}$ in late February. Ice deterioration began in late March and the

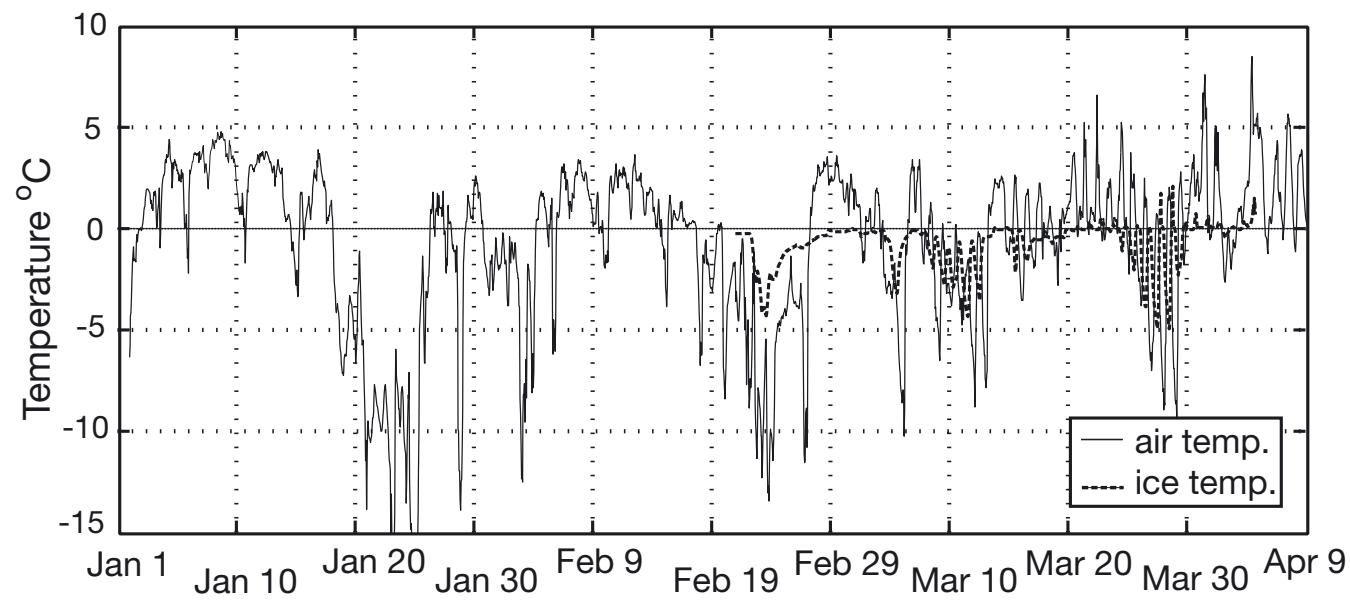

Fig. 2. Air temperature ( $2 \mathrm{~m}$ height) and ice temperature $(15 \mathrm{~cm}$ from ice surface) approximately $200 \mathrm{~m}$ away from sampling site used from 25 January 2000 onward. Continuous ice temperature records were available from 22 February onward (modified from Granskog et al. 2003) 
ice disappeared in mid-April. During the entire study period, the ice was only occasionally covered with a thin snow layer. Winter 2000 was milder than the average winters in the study area, air temperature remaining above zero for several days during the first half of January, in mid-February, in early March and again in mid-March (present Fig. 2 and Granskog et al. 2003). Warm weather caused ice-sheet warming (Fig. 2) and ice desalination, which could be seen clearly in the ice salinity data (Fig. 3). After a major drop in ice salinity on 22 February salinity in the lower ice increased again from 8 to 14 March. The effect of weather conditions on the physical properties of ice is discussed in detail in Granskog et al. (2003).

\section{Chl a, POC/PON}

The temporal variations in ice chl a concentration were remarkable (Fig. 3). The first maximum, with a

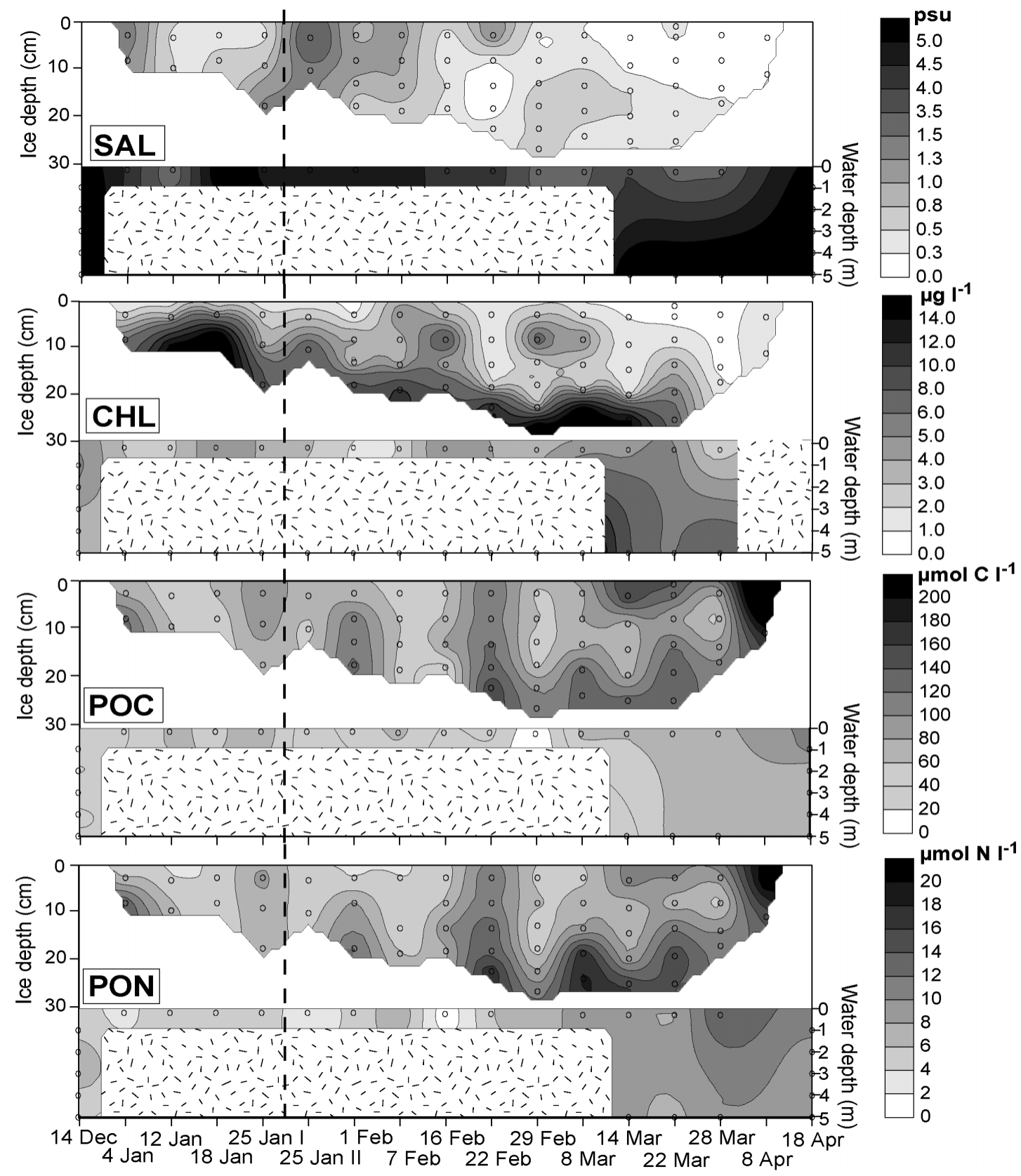

Fig. 3. Salinity (SAL) and concentrations of chlorophyll a (CHL), particulate organic carbon (POC) and particulate organic nitrogen (PON) in sea ice and underlying water. Dot overlay map shows actual data points, vertical dashed line denotes change in sampling location on 25 January (I: near shoreline; II: mid-bay sampling). Scales in SAL and CHL are nonlinear 
chl a concentration of $18.5 \mu \mathrm{g}^{-1}$, developed in midJanuary in $\sim 10 \mathrm{~cm}$ thick ice without snow cover. After the sampling-point change, chl a concentrations soon reached 6 to $8 \mathrm{\mu g} \mathrm{l}^{-1}$ in the lowermost layer of the new ice, and 2 wk later increased throughout the ice column. Chl a concentrations decreased in the upper and middle parts of the ice column during 16 to 22 February and increased in the lowermost ice layer and under-ice water. The main interior chl a maximum developed during March in the lowermost $10 \mathrm{~cm}$ of ice, with a peak concentration of $18.7 \mu \mathrm{g} \mathrm{l}^{-1}$. Chl a concentrations decreased to below $1 \mu \mathrm{g} \mathrm{l}^{-1}$ in late March. The chl a concentration in the underlying water remained low, then increased simultaneously with an increase in ice chl $a$, and a clear bloom of the diatom Skeletonema costatum was formed, which then rapidly sank to the bottom waters (Fig. 3).

The overall mean concentration of POC in the sea ice was significantly higher than in the underlying water (Mann-Whitney $U$-test, $p=0.010$, Table 1). Two types of POC maximum were distinguished in the ice: (1) POC maxima with an even vertical distribution on 1 and 22 February as well as on 8 April (Fig. 3); (2) a maximum in the lower ice during March in connection with the observed increase in chl a. The PON level correlated significantly (Spearman's $\mathrm{r}=0.850, \mathrm{p}<0.001, \mathrm{n}=58$ ) with the POC level, with a similar distribution pattern (Fig. 3). The POC concentration in the underlying water was lower or similar to that in the sea ice (Mann-Whitney $U$-test, $\mathrm{p}=0.145$ ) and increased only slightly toward late March. The POC and PON concentrations in precipitation were 37.6 to 65.2 and 6.7 to $8.5 \mu \mathrm{mol} \mathrm{l}^{-1}$, respectively.

When using a chl a/carbon ratio of 23 (Haecky et al.1998), algal carbon comprised a mean of $13 \pm 14 \%$ of the POC in ice over the entire study period. During the $2 \mathrm{chl}$ a maxima, algal carbon formed up to $65 \%$ of the POC. The total biomass of ice organisms (excluding the ciliate and metazoan biomasses) displayed a maximum of $69 \%$ on 18 January and a mean of $15 \pm 15 \%$ of the POC for the entire study period. Toward the end of the season, the percentage of carbon in POC present in living organisms decreased (mean ice values $23 \pm 19 \%$ in January, $17 \pm 15 \%$ in February and $9 \pm 12 \%$ in March to April). During the entire study period, the proportion of algal biomass comprised a mean of $82 \pm 10 \%$ of organism biomass in the ice. The mean POC/PON ratio in ice samples was $9.6 \pm 8.8$, which is well above the Redfield ratio. The mean PON concentration over the entire study period in the sea ice was significantly higher than in the underlying water (Mann-Whitney $U$-test, $p=0.001$ ). The mean PON in sea ice made up $30 \pm 19 \%$ of $\mathrm{TN}$, and in association with the ice chl a maxima up to $50 \%$ of TN.

\section{Total bacteria number and biovolume}

The mean TBN and bacterial biomass in the ice were approximately one-third of the under-ice water values (Table 2). The initial TBN was high upon ice formation, but decreased over $2 \mathrm{wk}$ along with an increase in total leucine incorporation (TLI) and BVOL (Fig. 4). The TBN decreased in the upper ice layers in late February, but remained high in the lower ice. The bacterial biomass formed a mean of $16.7 \pm 9.4 \%$ of organism bio-

Table 1. Concentrations of particulate organic carbon (POC) and nitrogen (PON) $\left(\mu \mathrm{g} \mathrm{l}^{-1}\right)$. Values are mean $\pm \mathrm{SD}$ (range); $\mathrm{n}$

\begin{tabular}{|c|c|c|}
\hline & POC & PON \\
\hline Ice & $1049.0 \pm 506.8(363.0-3139.7)_{;} 58$ & $125.1 \pm 59.1(5.6-272.2) ; 58$ \\
\hline Under-ice water & $888.2 \pm 417.1(451.4-1836.6) ; 16$ & $97.2 \pm 45.3(52.6-197.6) ; 16$ \\
\hline Open water & $661.3 \pm 89.6 \quad(351.6-1132.6) ; 10$ & $92.5 \pm 22.6(60.8-132.0) ; 10$ \\
\hline
\end{tabular}

Table 2. Abundance of algae ( $\left.\mu \mathrm{g} \mathrm{chl} \mathrm{a}^{-1}\right)$ and of bacteria, flagellates and protozoans (cells ml ${ }^{-1}$ ) and carbon biomass $\left(\mu \mathrm{C} \mathrm{C}^{-1}\right.$ ). Values are mean $\pm \mathrm{SD}$ (range); $\mathrm{n}$

\begin{tabular}{|lll|}
\hline \multicolumn{2}{|c|}{ Abundance } & Biomass \\
\hline Algae & & \\
Ice & $4.4 \pm 4.6(0.5-18.7) ; 59$ & $102.2 \pm 104.6(11.7-429.7) ; 59$ \\
Under-ice water & $5.1 \pm 2.0(1.9-19.1) ; 17$ & $116.3 \pm 45.1(43.3-438.6) ; 17$ \\
Open water & $3.3 \pm 0.8(3.4-5.3) ; 5$ & $96.8 \pm 19.3(77.8-120.7) ; 5$ \\
Bacteria & & \\
Ice & $5.3 \pm 2.9 \times 10^{5}\left(0.9-14.5 \times 10^{5}\right) ; 59$ & $13.6 \pm 8.3(2.1-48.2) ; 59$ \\
Under-ice water & $1.8 \pm 0.3 \times 10^{6}\left(1.2-2.2 \times 10^{6}\right) ; 17$ & $33.6 \pm 7.6(25.0-50.3) ; 17$ \\
Open water & $2.2 \pm 0.4 \times 10^{6}\left(1.6-2.8 \times 10^{6}\right) ; 10$ & $34.3 \pm 6.9(25.8-46.9) ; 10$ \\
Heterotrophic flagellates & \\
Ice & $22.2 \pm 18.2(0.0-78.4) ; 60$ & $1.5 \pm 1.4(0.01-5.6) ; 59$ \\
Under-ice water & $39.0 \pm 17.4(9.0-72.7) ; 16$ & $1.0 \pm 0.4(0.4-2.6) ; 16$ \\
Open water & $41.0 \pm 39.4(18.2-56.6) ; 10$ & $0.6 \pm 0.4(0.1-1.3) ; 10$ \\
Autotrophic flagellates & \\
Ice & $38.5 \pm 44.5(0.8-220.5) ; 60$ & $1.6 \pm 2.4(0.0-12.5) ; 59$ \\
Under-ice water & $171.0 \pm 247.6(31.8-1013.8) ; 16$ & $2.0 \pm 1.8(0.6-8.0) ; 16$ \\
Open water & $234.4 \pm 252.2(19.3-636.4) ; 10$ & $3.7 \pm 2.3(1.1-7.9) ; 10$ \\
Protozoa & & \\
Ice & $1.9 \pm 2.9(0-10.1) ; 19$ & $2.7 \pm 4.4(0-17.4) ; 19$ \\
Under-ice water & $12.2 \pm 12.7(0.5-32.3) ; 7$ & $9.6 \pm 6.1(1.3-18.2) ; 7$ \\
\hline
\end{tabular}



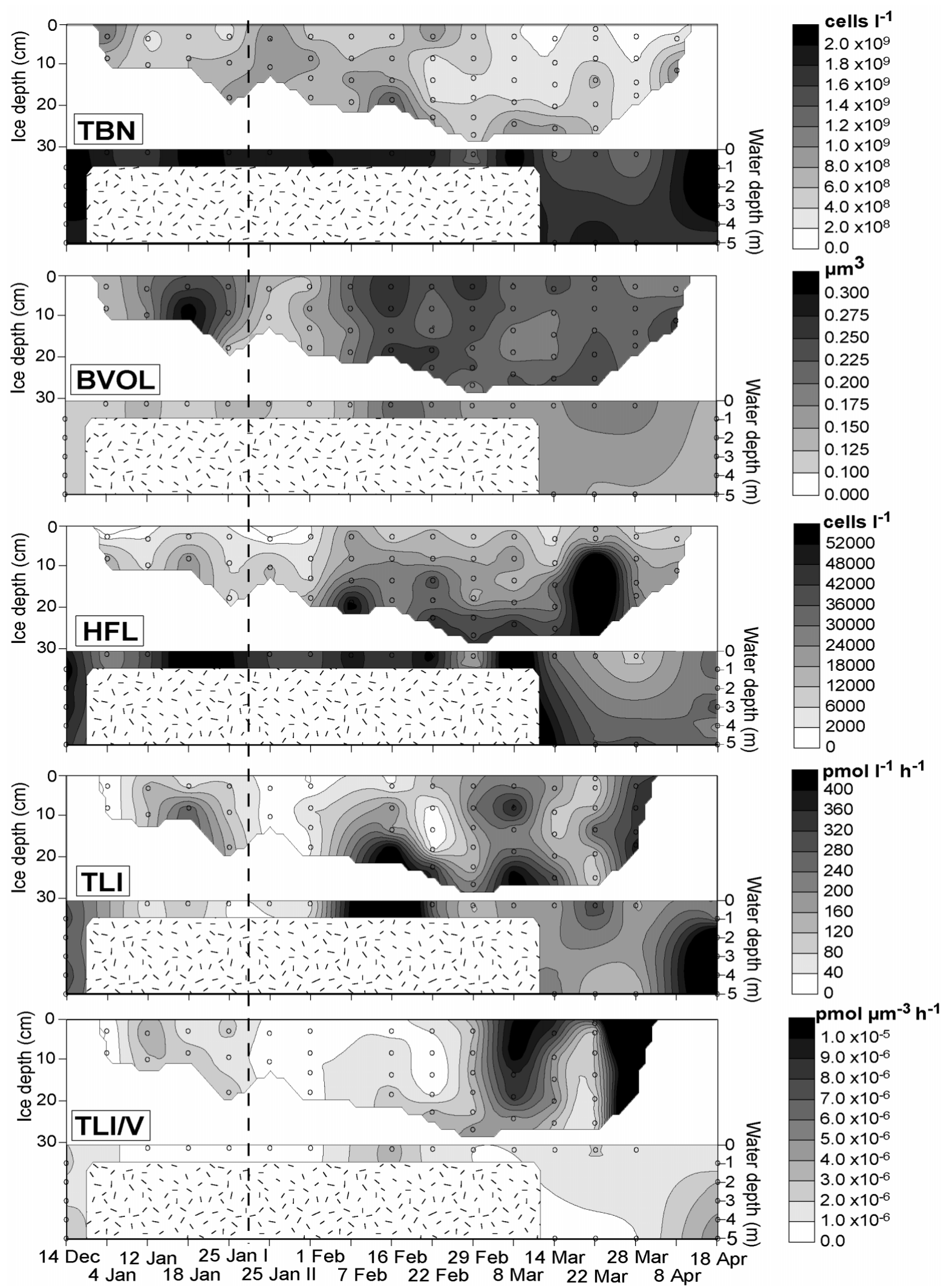

Fig. 4. Total bacterial number (TBN), average bacterial cell volume (BVOL), abundance of heterotrophic flagellates (HFL), total leucine incorporation (TLI) and volume-specific leucine incorporation (TVI/V) in sea ice and water. Further details as in Fig. 3. Scales in BVOL and HFL are nonlinear 
mass in the ice and $27.6 \pm 7.5 \%$ in the under-ice water (Table 2).

The mean BVOL of sea ice bacteria over the entire study period was $0.208 \pm 0.044{\mu m^{3}}^{3}$, while in the underlying water bacteria were significantly smaller $\left(0.154 \pm 0.032 \mu^{3}\right.$, Mann-Whitney's $U$-test, $\left.\mathrm{p}=0.000\right)$. After ice formation on 4 January, the mean BVOL in the ice increased 2-fold in 2 wk (from 0.133 to $0.279 \mu^{3}$, Fig. 4). Similarly, the BVOL increased from 0.119 to $0.258 \mu^{3}$ in $3 \mathrm{wk}$ after the change in sampling point and new ice formation on 25 January. A maximum mean BVOL of $0.320 \mu^{3}$ for the whole ice column was measured on 18 January in association with a high chl a value. The BVOL decreased temporarily on 22 February and again in early March. The vertical distribution of BVOL was mainly even and changed simultaneously in the entire ice column. In contrast to the BVOL maximum observed in late January, no distinct BVOL maximum could be seen in association with the chl a maximum in March. The BVOL in the under-ice water increased from 16 to 22 February simultaneously with the peak in ice nutrient concentrations and salinity decrease. From there on, the mean BVOL in the water was higher than in the early season; only after ice break-up did it return to lower open-water values.

\section{Bacterial secondary production}

As in the BVOL and in chl $a$, a clear succession in TLI occurred in the sea ice. (Fig. 4). After ice formation (4 January) the TLI values increased rapidly 80 -fold in $1 \mathrm{wk}$; from 25 January on the increase was 1.5 -fold. A clear decrease in TLI occurred on 22 February similar to that observed in almost all the other parameters measured. High TLI values later on followed the increase in chl a. Bacterial carbon production in the ice

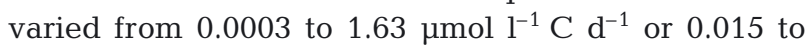
$81.5 \mu \mathrm{mol} \mathrm{C} \mathrm{m}^{-2} \mathrm{~d}^{-1}$; the areal mean value over the entire study period was $27.1 \pm 19.3 \mu \mathrm{mol} \mathrm{C} \mathrm{m} \mathrm{C}^{-2} \mathrm{~d}^{-1}$. The TLI values were equal in the ice and underlying water (Mann-Whitney $U$-test, $\mathrm{p}=0.735$, Table 3). The TLI clearly increased on 16 February and after ice breakup in the underlying water. The mean values of the production/biomass (P/B) ratio for the entire ice col- umn were low soon after ice formation on 4 and 25 January (0.005 and $0.07 \mathrm{~d}^{-1}$, respectively) but increased rapidly in 1 to $2 \mathrm{wk}$, the average value over the study period was $0.70 \pm 0.93 \mathrm{~d}^{-1}$. The $\mathrm{P} / \mathrm{B}$ ratio varied between 0.04 and $0.53 \mathrm{~d}^{-1}$ in underlying water, and between 0.19 and $0.73 \mathrm{~d}^{-1}$ in open water, with mean values of $0.16 \pm 0.13$ and $0.43 \pm 0.17 \mathrm{~d}^{-1}$, respectively. TLI and ice-algae biomass were significantly correlated (Spearman's $\mathrm{r}=0.332, \mathrm{p}=0.0015, \mathrm{n}=53$ ).

Bacterial biovolume-specific leucine incorporation (TLI/V) was calculated (as TLI/V = TLI/[TBN $\times$ BVOL]) to reveal changes in the activity of the ice-bacterial population. The mean TLI/V over the entire study period was 5 times higher in the ice than in the underice water and twice as high as the open-water values (Table 3). The TLI/V generally followed the succession of TLI in January and February (Fig. 4). On 8 and 28 March 2 clear maxima in TLI/V occurred throughout the ice column.

\section{Abudance of flagellates, ciliates and metazoans}

The 2 smallest size classes of flagellates dominated total flagellate abundance (Fig. 5). The mean flagellate size distribution and abundance in the whole ice column for all sampling days are presented in Fig. 5, and biomass over the entire study period in Table 2 . The HFL biomass constituted $0.017 \pm 0.019 \%$ of organism biomass in the ice and $0.006 \pm 0.002 \%$ in the underlying water. HFLs were found throughout the ice column and were most abundant at the ice-water interface and the underlying water (Fig. 4). After ice formation, the abundance of HFLs increased almost as fast as BVOL and TLI. Small peaks in abundance could be seen in the lower ice on 18 January and on 7 and 22 February. In contrast to several other parameters, the abundance of HFLs in ice increased on 22 February. The HFL abundance peaked on 22 March and decreased during the following week.

AFLs were found early in the season in the entire ice column but were present in mid-February only in the lowermost $10 \mathrm{~cm}$ of ice. After ice formation, the abundance of AFLs peaked but then decreased drastically within 1 wk (on 25 January and 16 February) and remained low (Fig. 5). AFLs contributed a maximum

Table 3. Bacterial production, as total leucine incorporation (TLI; pmol l-1 $\mathrm{h}^{-1}$ ), carbon production $\left(\mathrm{mg} \mathrm{C}^{-1} \mathrm{~h}^{-1}\right.$ ) and volume-specific TLI $\left(p m o l \mu \mathrm{m}^{-3} \mathrm{~h}^{-1}\right)$. Values are mean $\pm \mathrm{SD}($ range $) ; \mathrm{n}$

\begin{tabular}{|llll|}
\hline & Total leucine incorporation (TLI) & Carbon production & Volume-specific TLI (TLI/V) \\
\hline Ice & $84.2 \pm 62.5(0.1-244.2) ; 53$ & $0.3 \pm 0.2(0.0-0.7) ; 54$ & $1.2 \pm 1.6 \times 10^{-6}\left(8.3 \times 10^{-10}-9.5 \times 10^{-6}\right) ; 53$ \\
Under-ice water & $85.9 \pm 87.2(16.5-368.2) ; 15$ & $0.2 \pm 0.3(0.0-1.1) ; 15$ & $2.9 \pm 2.1 \times 10^{-7}\left(6.3 \times 10^{-8}-9.2 \times 10^{-7}\right) ; 15$ \\
Open water & $199.4 \pm 83.5(106.7-319.1) ; 10$ & $0.6 \pm 0.2(0.3-1.0) ; 10$ & $7.4 \pm 3.0 \times 10^{-7}\left(3.2 \times 10^{-7}-1.3 \times 10^{-6}\right) ; 10$ \\
\hline
\end{tabular}



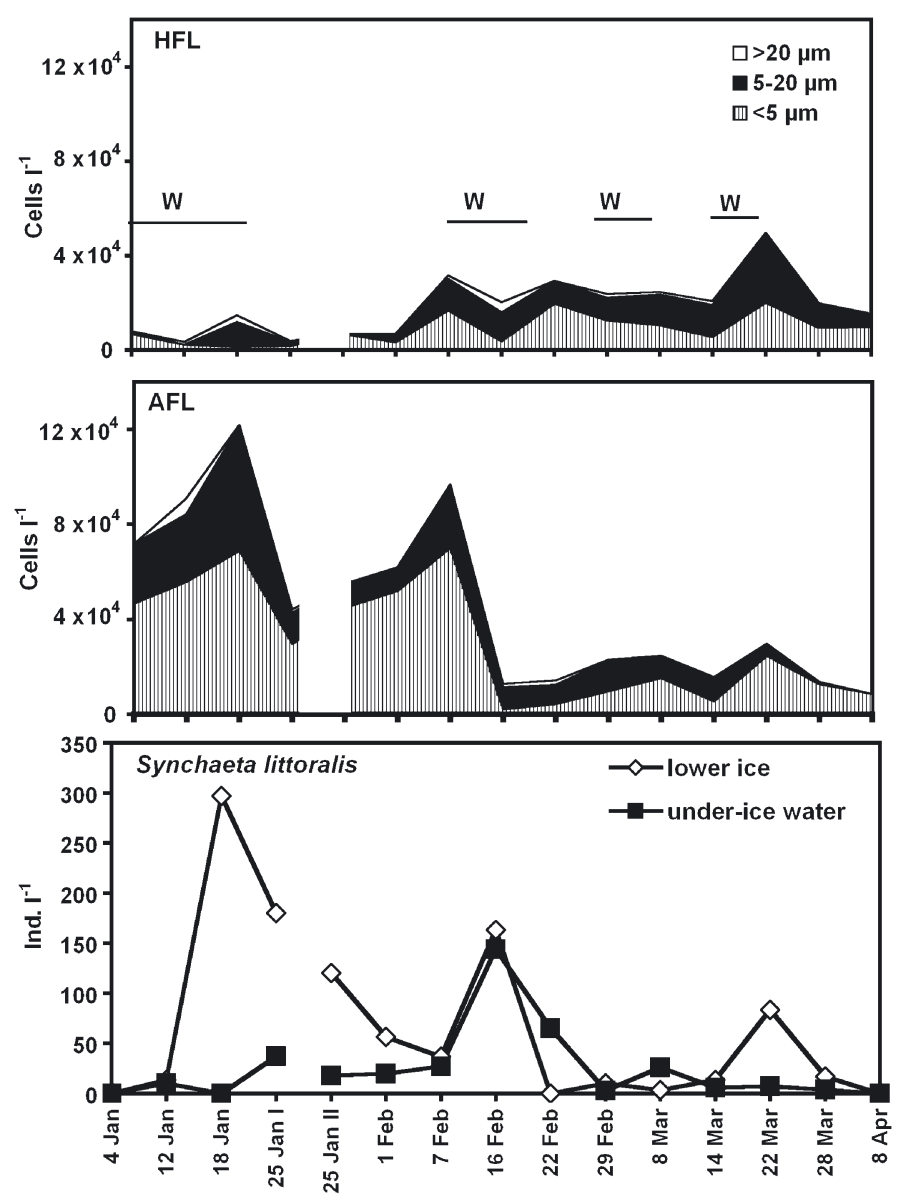

Fig. 5. Abundance of heterotrophic (HFL) and autotrophic flagellates (AFL) in sea ice (ice-column average values) and abundance of rotifer Synchaeta littoralis $(>40 \mu \mathrm{m})$ in lowermost $10 \mathrm{~cm}$ of sea ice and in under-ice water. W: warm periods;

25 Jan I: near shore-line; 25 Jan II: mid-bay sampling

of $4.1 \%$ of the ice-algae biomass on 4 January (mean $1.3 \pm 1.0 \%$ )

A diverse ciliate fauna comprising several different size classes was found inside and in association with the ice. The ciliate community composition changed substantially during March; on 8 March, ciliate biomass was high in the entire ice column, consisting mainly of Strombidium styliferum, Strombidium spp. and various unidentified ciliates with equivalent spherical diameters (ESD) of 10 to $30 \mu \mathrm{m}$. Their biomass disappeared within $1 \mathrm{wk}$, and larger, probably predatory, ciliates such as Lacrymaria spp. became more abundant in the lower $10 \mathrm{~cm}$ of ice toward late March. Photosynthetic or mixotrophic ciliate species such as Bursaria sp., and Mesodinium rubrum were found in ice and under-ice water in March. The abundance of $M$. rubrum in the lower ice increased toward

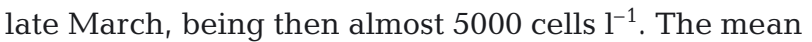
protozoan biomass in the ice is presented in Table 2. The mean ice-ciliate biomass (including $M$. rubrum) in March was $0.4 \pm 0.3 \%$ of the POC value and $5.2 \pm 4.0 \%$ of the organism biomass.

Metazoans found in the ice comprised mainly rotifers of the species Synchaeta littoralis (40 to $100 \mu \mathrm{m}$ in size) and its eggs, as well as some occasional calanoid (Acartia bifilosa) and cyclopoid nauplii. The $S$. littoralis abundance peaks in the ice on 18 January and 22 March coincided with warm periods and the abundance of flagellates (Fig. 5). Ice rotifer abundance peaked on 16 February in the ice and underlying water concurrent with the ice-salinity drop and increase in AFL numbers in the underlying water. Ice metazoans made up a mean of $0.3 \pm 0.2 \%$ of the POC and $4.4 \pm$ $4.8 \%$ of the organism biomass in March.

\section{Nutrients}

Dissolved and total phosphorus and nitrogen were measured in the melted sea ice, water and precipitation samples. The actual range of nutrient concentrations is given in Table 4, whereas the concentrations presented in Fig. 6 are normalized. The actual concentrations of dissolved and total nutrients were generally lower in the ice than in the under-ice water, with the exception of $\mathrm{NH}_{4}{ }^{+}-\mathrm{N}$ (Mann-Whitney $U$-tests, $\mathrm{p}=$ 0.000 for all nutrients, except for TP $\mathrm{p}=0.002$, Table 4 ). The seawater salinity-normalized nutrient concentrations in the sea ice were higher than in the underlying water. Precipitation contained high concentrations of

Table 4. Dissolved and total nutrient concentrations $\left(\mu \mathrm{mol} \mathrm{l}^{-1}\right)$ in sea ice and water, non-normalized values for dissolved nutrients. DON: dissolved organic nitrogen; TP: total phosphorus

\begin{tabular}{|lcccccccc|}
\hline & $\mathrm{n}$ & $\mathrm{PO}_{4}{ }^{3-}$ & $\mathrm{NH}_{4}{ }^{+}$ & $\mathrm{NO}_{3}{ }^{-}$ & $\mathrm{NO}_{2}{ }^{-}$ & $\mathrm{DON}$ & $\mathrm{TP}$ \\
\hline Ice & \multirow{2}{*}{56 to 59} & $0.1 \pm 0.1$ & $2.7 \pm 2.3$ & $3.6 \pm 2.7$ & $0.1 \pm 0.1$ & $17.7 \pm 11.0$ & $0.4 \pm 0.2$ & $32.2 \pm 12.2$ \\
& & $(0.0-0.2)$ & $(0.4-13.1)$ & $(0.4-18.5)$ & $(0.0-0.3)$ & $(0.5-59.3)$ & $(0.1-0.9)$ & $(15.5-75.0)$ \\
Under-ice water & \multirow{2}{*}{16 to 17} & $0.2 \pm 0.1$ & $1.4 \pm 1.3$ & $8.1 \pm 3.9$ & $0.4 \pm 0.3$ & $28.9 \pm 9.7$ & $0.6 \pm 0.2$ & $45.0 \pm 11.1$ \\
& & $(0.1-0.4)$ & $(0.0-5.1)$ & $(0.1-14.8)$ & $(0.0-0.8)$ & $(14.1-49.2)$ & $(0.3-1.0)$ & $(29.2-66.2)$ \\
Open water & \multirow{2}{*}{10} & $0.6 \pm 0.2$ & $0.5 \pm 0.1$ & $3.0 \pm 0.1$ & $0.4 \pm 0.4$ & $26.2 \pm 4.6$ & $0.6 \pm 0.2$ & $37.6 \pm 3.5$ \\
& & $(0.1-0.5)$ & $(0.4-0.8)$ & $(0.0-6.0)$ & $(0.0-0.8)$ & $(21.2-33.8)$ & $(0.3-0.8)$ & $(32.0-42.4)$ \\
& & & & & & & &
\end{tabular}




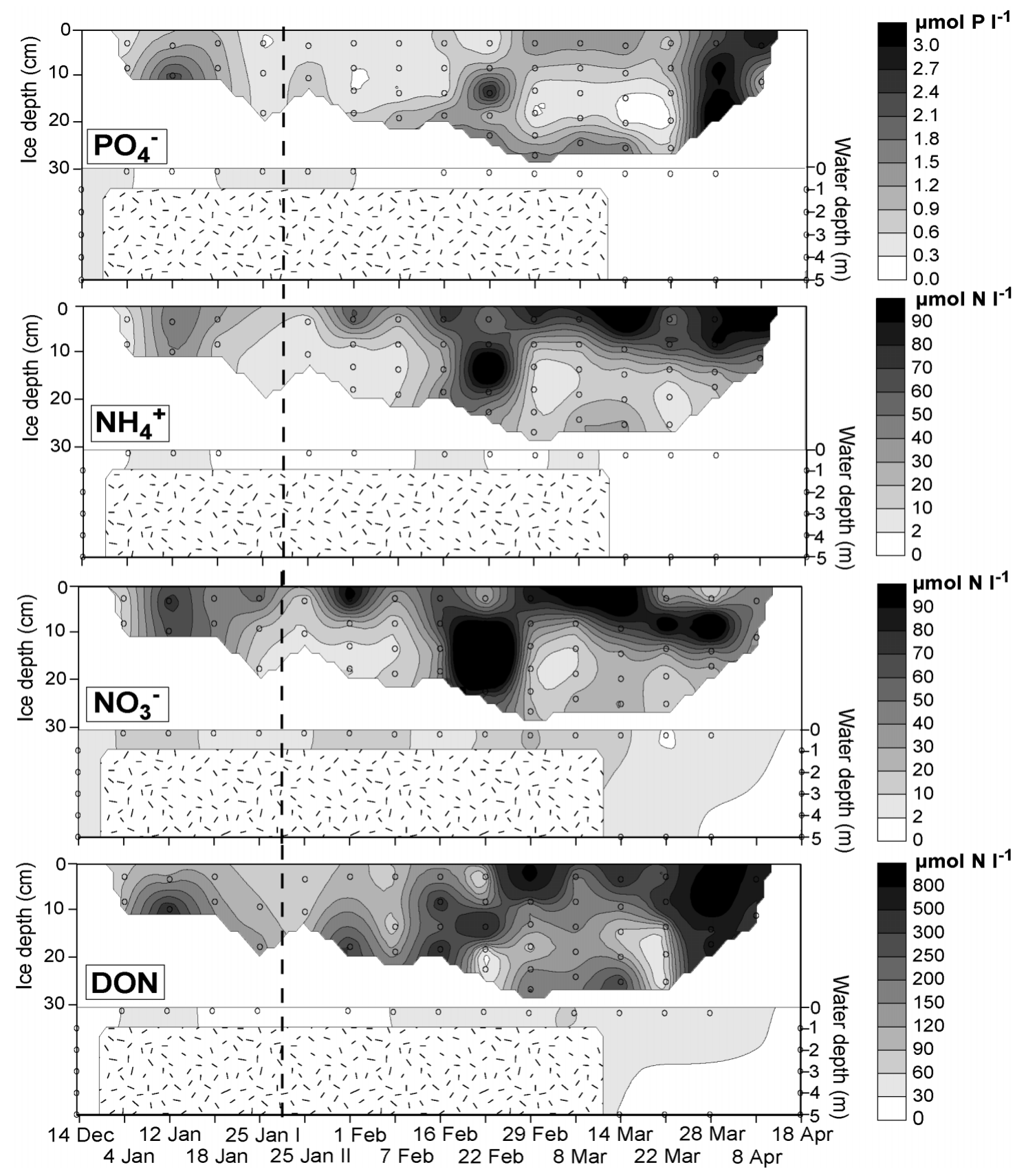

Fig. 6. Normalized concentrations of dissolved nutrients in sea ice and water. Further details as in Fig. 3, note nonlinear scales for $\mathrm{NH}_{4}{ }^{+}, \mathrm{NO}_{3}{ }^{-}$and DON

nitrogenous nutrients, mainly $\mathrm{NH}_{4}{ }^{+}$and $\mathrm{NO}_{3}{ }^{-}$(26.8 to $31.7 \mu \mathrm{mol} \mathrm{l} \mathrm{l}^{-1} \mathrm{NH}_{4}{ }^{+}-\mathrm{N}, 49.4$ to $79.7 \mu \mathrm{mol} \mathrm{l^{-1 }} \mathrm{NO}_{3}{ }^{-}-\mathrm{N}$, 141.3 to $\left.171.6 \mu \mathrm{mol} \mathrm{l}^{-1} \mathrm{TN}\right)$.

Some common trends could be seen in the nutrient data: (1) clear maxima in all dissolved nutrients in the ice occurred in association with warm periods in January, mid-February and mid-March; (2) the uppermost ice had elevated concentrations of nitrogenous nutrients; (3) activity of ice organisms affected the concentrations of $\mathrm{NH}_{4}{ }^{+}-\mathrm{N}$ and $\mathrm{PO}_{4}{ }^{3-}-\mathrm{P}$.
The mean concentration of $\mathrm{PO}_{4}{ }^{3-}$-P in the ice was lower than in the under-ice water. In normalized data, elevated $\mathrm{PO}_{4}{ }^{3-}$-P concentrations were found in association with a chl a maximum in the lowermost ice layers (Spearman's $\mathrm{r}$ between $\mathrm{chl} \mathrm{a}$ and $\mathrm{PO}_{4}{ }^{3-}-\mathrm{P}$ in ice $=0.323$, $\mathrm{p}<0.05, \mathrm{n}=59$, Figs. 3 \& 6). A clear $\mathrm{PO}_{4}{ }^{3-}-\mathrm{P}$ maximum in the entire ice column was also detected on 28 March. TP was found in similar concentrations in the lower parts of the ice and underlying water until 22 March, when the concentrations in ice and water 
decreased. In the upper ice, the TP concentration was low until it slightly increased late in the ice season (data not shown).

The measured nitrogenous nutrients include $\mathrm{NH}_{4}{ }^{+}-\mathrm{N}$, $\mathrm{NO}_{2}{ }^{-}-\mathrm{N}, \mathrm{NO}_{3}{ }^{-}-\mathrm{N}$ and TN (Table 4, Fig. 6). The $\mathrm{NH}_{4}{ }^{+}-\mathrm{N}$ concentration in the lower part of the ice and underlying water remained low, until slightly elevated concentrations were observed first on 22 February and later in association with the March chl a maximum. The $\mathrm{NO}_{3}{ }^{-}-\mathrm{N}$ concentrations in the ice followed a pattern similar to $\mathrm{NH}_{4}{ }^{+}-\mathrm{N}$ (Spearman's $\mathrm{r}=0.634, \mathrm{p}<0.000$, $\mathrm{n}=58$ ), with high concentrations in the upper ice and a slight elevation in association with high chl a (Figs. 3 \& 6). The normalized $\mathrm{NO}_{3}{ }^{-}-\mathrm{N}$ concentration was higher than the under-ice water concentrations, the actual values of $\mathrm{NO}_{3}{ }^{-}-\mathrm{N}$ in ice being twice as high as in the underlying water (Fig. 6). The concentration of TN was slightly lower in the ice than in the underlying water (Table 4).

The calculated concentration of DON in ice fluctuated widely and rapidly (Fig. 6). The actual DON concentrations in the ice were approximately $30 \%$ lower than in the underlying water (Table 4 ). The normalized DON concentration in the ice showed a distribution pattern closely resembling that of $\mathrm{PO}_{4}{ }^{3-}$-P distribution, and these 2 were significantly correlated (Spearman's $\mathrm{r}=0.570, \mathrm{p}<0.000, \mathrm{n}=58$ ). Investigation of small-scale spatial variability in the ice in the sampling area on 14 March revealed that coefficients for spatial variation inside the measured $4 \mathrm{~m}$ transect were generally remarkably lower than for temporal variation in the same ice layer (Table 5). For POC and DON, spatial variability was higher, being almost as high as temporal variability.

Table 5. Variation coefficients (CV) for small-scale spatial and temporal variability in 5 to $12 \mathrm{~cm}$ (below ice surface) layer. For spatial variability, measurements from $4 \mathrm{~m}$ transect on 14 March are used; temporal variability comprises samples from 25 January to 8 April 2000. SAL: salinity; CHL: chlorophyll $a_{i}$ TBN: total bacteria number; HFL: heterotrophic flagellates; AFL: autotrophic flagellates; other abbreviations as in Tables $1,3 \& 4$

\begin{tabular}{|lcc|}
\hline Parameter & Spatial CV(\%) & Temporal CV $(\%)$ \\
\hline SAL & 23.1 & 90.6 \\
CHL & 17.6 & 70.9 \\
POC & 37.9 & 59.6 \\
PON & 50.0 & 52.0 \\
TBN & 12.5 & 55.5 \\
TLI & 14.3 & 78.1 \\
$\mathrm{HFL}$ & 32.3 & 81.3 \\
$\mathrm{AFL}$ & 35.8 & 81.8 \\
$\mathrm{PO}_{4}{ }^{3-}-\mathrm{P}$ & 20.2 & 76.6 \\
$\mathrm{NH}_{4}{ }^{+}-\mathrm{N}$ & 13.0 & 39.8 \\
$\mathrm{NO}_{3}{ }^{-}-\mathrm{N}$ & 21.3 & 37.4 \\
$\mathrm{DON}^{-}$ & 47.4 & 55.0 \\
\hline
\end{tabular}

\section{DISCUSSION}

\section{Successional dynamics}

The seasonal development of ice-algae communities differed from those described in earlier studies of Baltic sea ice, since the first ice-algae bloom appeared already in mid-January in thin ice without snow cover. These early-January blooms have not been reported in the Gulf of Bothnia, where algal biomass remains low during the winter months and the only bloom begins in late March as a response to increasing irradiation (Norrman \& Andersson 1994, Haecky \& Andersson 1999). However, the occurrence of the January bloom may also have been related to local physical aspects, such as selective organism incorporation into the ice (Spindler 1994). It must also be stressed that the situation in near-shore ice sampled in January does not necessarily represent the general situation of sea ice in the area. The algal biomass remained high in the lowermost ice through February, and the main bloom of ice diatoms developed during March (Fig. 3). After bloom termination in late March, the DON and $\mathrm{PO}_{4}{ }^{3-}$-P concentrations, bacterial secondary production and number of HFLs increased (Figs. 3, 4 \& 6). Based on chl $a$, ice-algae biomass fell within the same range as in earlier studies conducted on Baltic sea ice (Norrman \& Andersson 1994, Mock et al. 1997, Haecky et al. 1998, Haecky \& Andersson 1999, Meiners et al. 2002). The sea ice organism assemblage was clearly autotrophy-dominated, the algal biomass comprising a mean of $82 \pm 10 \%$ of the organism biomass. The bacteria were the most important heterotrophic organism group by biomass $(16.7 \pm 9.4 \%)$. Based only on data from March, the protozoan and metazoan biomasses also formed a remarkable portion of organism biomass (4.5 \pm 2.7 and $4.4 \pm 4.8 \%$, respectively), while HFLs showed only a minor percentage (averaging $0.019 \pm$ $0.017 \%$ over the entire study period) of the biomass. The POC concentration in the ice mainly represented the nonliving fraction, and the share of POC found in living organisms decreased during the winter. However, the algal biomass estimation used is not sensitive to variation in the $\mathrm{chl}$ a/carbon ratio of the algal community. The vertical POC maxima during periods of warm weather (Fig. 3), high concentrations of POC in atmospheric fallout, and a particulate $\mathrm{C} / \mathrm{N}$ molar ratio exceeding the Redfield ratio in ice indicate potential introduction of allochthonous POC into the ice. According to the test performed on 14 March, spatial variability along the $4 \mathrm{~m}$ transect (which corresponds to the size of the sampling plot where successive samples were obtained) was remarkably smaller than temporal variability (Table 5). Therefore, the observed patterns in the measured parameters in sea ice are 
generally presumed to represent the actual temporal succession. Only POC and DON had high spatial variability, which may reduce the reliability of the observed temporal patterns of these parameters.

\section{Regulation of algal growth}

Nutrient concentrations in the ice and in the underice water (Table 4) were lower than the concentrations measured in the southern Baltic (Mock et al. 1997) and Bothnian Sea (Norrman \& Andersson 1994), but in the same range as reported by Meiners et al. (2002) from the northern Baltic Sea. The accumulation of ice-algae biomass in the Gulf of Bothnia is dependent on the amount of available nutrients, particularly $\mathrm{P}$, trapped inside the ice during the ice-algae bloom period (Haecky \& Andersson 1999). Granskog et al. (2003) suggest that a physical forcing-driven nutrient supply into the ice can be the determining factor in nutrient dynamics and also important for primary productivity of Baltic sea ice. Warm periods (Fig. 2) and associated changes in ice permeability (Granskog et al. 2003) visibly affected chemical and biological properties of the ice. Ice desalination, indicating brine drainage during the warm periods, could be seen in the salinity data (Fig. 3). From 16 to 22 February, chl a concentration and TBN decreased throughout the ice column and in mid-March in the upper ice. This indicates that temperature and the permeability evolution of the ice controlled ice-algae biomass, analogously to the results of (Krembs et al. 2001) for an experimental ice system. The upper part of the ice contained high concentrations of nitrogenous nutrients obviously of atmospheric origin. Maxima in normalized dissolved nutrients inside the ice on 12 January and from 16 to 22 February and in the upper ice on 1 February and 14 March (Fig. 6) probably resulted from ice-sheet warming, subsequent ice-flushing (Granskog et al. 2003) and transport of nutrients inside the ice. The physical properties of the ice may thus have controlled algal growth through nutrient availability as well as brine stability. Nutrient and organic matter transport across the ice-water interface took place during the warm period in February; chl $a$, number of AFLs, BVOL and TLI decreased in the sea ice and increased in the underlying water. Via taxon-specific drainage rates of ice algae (Haecky \& Andersson 1999, Kaartokallio 2001), changes in ice permeability may also affect the algal community composition. Flagellated cells are reported to move more easily with brine than diatoms (Kaartokallio 2001), which is consistent with the observation of a 3 -fold increase in AFL numbers (from 0.4 to $1.5 \times$

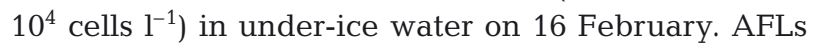
constituted only a minor part of algal biomass, and the observed decrease in chl $a$ in the upper and middle ice layers on 22 February may reflect the brine drainage transport of other more immobile taxa, e.g. diatoms.

The decreased concentrations of $\mathrm{NH}_{4}{ }^{+}-\mathrm{N}$ and $\mathrm{PO}_{4}{ }^{3-}-\mathrm{P}$ in the lower ice from late January to early February, as well as in middle ice layers in March probably resulted from nutrient uptake by ice algae (Fig. 6). Elevated concentrations, most likely produced by regeneration, were found in the lower ice in association with an ice-algae bloom and postbloom situation in March (Fig. 6). High $\mathrm{PO}_{4}{ }^{3-}-\mathrm{P}$ concentrations following the increase in HFL abundance suggest that these may have an active role as nutrient remineralizers, similar to the situation in Antarctic sea ice (Stoecker et al. 1993).

\section{Grazing control in ice food-web}

The TBN and BVOL (Fig. 4) were similar to those found in earlier studies for different parts of the Baltic Sea (Mock et al. 1997, Haecky \& Andersson 1999, Meiners et al. 2002). The average bacterial biomass in the ice remained relatively stable over the season (Table 6). An increase in bacterial cell size after ice formation was pronounced in the ice, while in underlying water the cell size remained more constant. An increase in bacterial cell size during ice growth was also reported by Grossmann \& Dieckmann (1994). Gradinger \& Zhang (1997) discussed the high DOM concentration inside the ice as a possible explanation for the increased bacterial cell volumes. In the present study the calculated DON was used to represent DOM;

Table 6. Mean carbon biomass $\left(\mu \mathrm{C} \mathrm{C}^{-1}\right.$ ) of algae (Alg), bacteria (Bact), heterotrophic flagellates (Hfl) and ciliates (Cil), and integrated bacterial carbon production in ice for each sampling occasion (Bpr, $\mu \mathrm{g} \mathrm{C}^{-1}$ ). Biomass change between successive sampling occasions is shown in $\Delta$ columns; $\Delta$ Bact includes Bpr and biomass change. Sampling on 25 January was (I) near shoreline and (II) mid-bay. ${ }^{*}$ : includes biomass change only

\begin{tabular}{|lrrrrrrrrr|}
\hline Date (2000) & Alg & $\Delta$ Alg & Bact & Bpr & $\Delta$ Bact & Hfl & $\Delta$ Hfl & Cil & $\Delta$ Cil \\
\hline 4 Jan & 92.5 & & 15.4 & 0.5 & & 0.2 & & & \\
12 Jan & 207.7 & 115.2 & 8.7 & 30.1 & -7.2 & 0.3 & 0.1 & & \\
18 Jan & 261.3 & 53.6 & 19.9 & 42.3 & -18.9 & 1.8 & 1.5 & & \\
25 Jan (I) & 109.5 & -151.8 & 13.3 & & -57.0 & 0.3 & -1.5 & & \\
25 Jan (II) & 118.0 & & 13.9 & 6.8 & & 0.0 & & & \\
1 Feb & 92.9 & -25.1 & 12.4 & 8.9 & -8.3 & 0.4 & 0.4 & & \\
7 Feb & 131.3 & 38.4 & 16.1 & & -5.2 & 1.8 & 1.4 & & \\
16 Feb & 130.4 & -0.9 & 27.8 & 74.8 & $11.7^{*}$ & 2.4 & 0.6 & & \\
22 Feb & 83.7 & -46.7 & 15.5 & 23.4 & -87.1 & 1.1 & -1.3 & & \\
29 Feb & 128.1 & 44.4 & 13.4 & 45.5 & -25.5 & 1.4 & 0.3 & & \\
8 Mar & 139.2 & 11.0 & 10.8 & 86.7 & -48.1 & 1.7 & 0.3 & 4.8 & \\
14 Mar & 68.8 & -70.4 & 8.6 & 37.8 & -88.9 & 1.8 & 0.1 & 0.8 & -4.0 \\
22 Mar & 71.5 & 2.8 & 14.2 & 37.8 & -32.2 & 3.3 & 1.5 & 4.5 & 3.7 \\
28 Mar & 17.0 & -54.5 & 4.3 & 74.1 & -47.7 & 1.1 & -0.4 & 2.2 & -2.3 \\
8 Apr & 42.6 & 25.5 & 19.3 & & -59.1 & 0.6 & -0.5 & & \\
& & & & & & & & & \\
\hline
\end{tabular}


the N-rich pool of sea ice DOM may be hydrolyzed more rapidly than the C-rich pool (Thomas et al. 1995, Guglielmo et al. 2000) and DON concentration thus may reflect the readily utilizable fraction of DOM. The calculated DON concentrations in sea ice were higher than those reported by Thomas et al. (1995) from Arctic sea ice. However, measurement of actual DOM levels in Baltic sea ice should be included in future studies to verify the calculated values presented here. Several reports on Arctic sea ice indicate tight coupling between bacterial biomass and DOM (Gradinger et al. 1992, Thomas et al. 1995 and references therein). The results of this study suggest that DOM was an important carbon source for ice bacteria, since high DON concentrations in ice on 12 January and on 1 and 29 February were followed by an increase in TLI within 1 wk (Figs. 4 \& 6). However, high spatial variability (Table 5) decreases the reliability of the seasonal pattern of DON. DOM in ice probably originated from degradation of $P O M$, and a highly significant, positive correlation existed between (regenerated) $\mathrm{PO}_{4}{ }^{3-}-\mathrm{P}$ and DON. The significant positive correlation between TLI and chl $a$ in ice suggests that organic carbon used by bacteria is at least partly derived from ice algae.

The succession of TLI after ice formation largely resembled the simultaneous succession in bacterial cell size (Fig. 4). Bacterial carbon production, with a mean value of $27.1 \pm 19.3 \mu \mathrm{mol} \mathrm{C} \mathrm{m}{ }^{-2} \mathrm{~d}^{-1}$ throughout the season, was higher than that reported by Haecky \& Andersson (1999) and equal to their postbloom maximum values. The P/B ratio was also higher throughout the season than those reported by Mock et al. (1997) and Haecky \& Andersson (1999). A high bacterial production and a high P/B ratio suggest that the sea ice bacteria were of great importance in the sea ice foodweb.

Both biomass and abundance of HFLs in ice (Table 2, Fig. 5) were significantly lower than those reported by Norrman \& Andersson (1994) and Haecky \& Andersson (1999) from the Gulf of Bothnia. The relatively constant bacterial biomass over the winter, despite the high P/B ratio (Table 6), indicates grazing on bacteria, although other mortality factors, e.g. viruses, cannot be excluded (Maranger et al. 1994). HFLs are generally considered as bacterial grazers, but another group of important consumers of ice bacteria may have been small ciliates, as reported for Antarctic sea ice (Delille et al. 2002). Small (ESD $20 \mu \mathrm{m}$ ) Strombidium spp. found in ice have been shown to select small food particles of the size of large bacteria (Kivi \& Setälä 1995). Assuming a growth efficiency of $20 \%$ for flagellates and small ciliates, the bacterial production and biomass change in March could have supported an HFL and small-ciliate biomass 2 to 10 times higher than that observed (Table 6). However, the flagellate and ciliate biomasses are net values and do not include a loss estimate. The 2 clear maxima in TLI/V (Fig. 4) probably resulted from intensive grazing on the ice-bacterial community. TBN and BVOL decreased from 22 to 29 February to 8 March in the middle and upper ice layers, as well as in thew middle and lower ice from 22 to 28 March (Fig. 4), corresponding to changes in TLI/V 1 wk later. Ciliate data from February is unfortunately not available, but small ciliates belonging mainly to the genus Strombidium were abundant throughout the entire ice column on $8 \mathrm{March}$; on 28 March another maximum in TLI/V was observed after the increase in the abundance of HFLs. Size-selective grazing could increase cell-specific production by removing larger cells and thus increasing the proportion of smaller, more actively metabolizing dividing cells.

The observed low flagellate biomass may have resulted from ciliate and metazoan grazing on small flagellates (Table 6) The metazoan fauna consisted primarily of rotifers of the species Synchaeta littoralis, whose abundance was as high, as in earlier published studies on Baltic sea ice (Norrman \& Andersson 1994, Meiners et al. 2002). Rotifers belonging to the genus Synchaeta are commonly considered as exploiters of small algal prey (Dolan \& Gallegos 1992) also in the Baltic sea ice environment (Haecky \& Andersson 1999). Synchaeta spp. found in ice were 40 to $100 \mu \mathrm{m}$ in size and presumably preyed mainly upon the 2 smallest size fractions of flagellates. The abundance of rotifers in the lower ice peaked on 25 January and 22 March at the same time as flagellate abundance (Fig. 5), which indicates metazoan grazing on flagellates. As changes in rotifer abundance were rapid in the ice, it is possible that they move across the ice-water interface for feeding in the ice; this is supported by observations of maximum abundance in the lowermost ice layers (Norrman \& Andersson 1994, Meiners et al. 2002) and 5 to 15 times higher rotifer abundance in $5 \mathrm{~m}$ depth compared to under-ice water (data from $5 \mathrm{~m}$ from 14 to 28 March only). Vertical migration of motile protists into the ice has been also discussed, e.g. by Stoecker et al. (1993). Periods of warm weather coincided with high flagellate and metazoan abundance in the lower ice (Fig. 5). Ice-warming and an increase in brine-channel diameter could allow metazoans to reach otherwise isolated channels and pockets inside the ice matrix (Krembs et al. 2000).

\section{Conclusions}

Except for the early onset of the first ice bloom in January, the ice-organism assemblages followed a characteristic annual succession, with a main algal bloom in March followed by bloom termination and 
increase in heterotrophy. The ice organisms were able to control the concentrations of dissolved nutrients inside the ice, and regeneration produced nutrients as the winter progressed. The present results suggest that sea ice bacteria are of great importance in the food web, and relationships between DON, bacterial production and algal biomass point also to the existence of a functional microbial loop in the ice. The bacteria and flagellate biomass was most probably controlled by HFL, ciliate and metazoan grazing. In addition to the size-structured grazing chain, 'shortcuts' such as ciliate grazing on bacteria and microflagellate herbivory by metazoans, which earlier studies also considered typical for sea ice food-webs, were likely to occur in the studied ice (e.g. Stoecker et al. 1993, Laurion et al. 1995, Sime-Ngando et al. 1997, Vezina et al. 1997). In addition to internal dynamics, ice-organism communities and their interactions were subject to varying weather conditions and subsequent changes in the physical properties of the ice (Granskog et al. 2003). These physical properties possibly control the growth and composition of the ice-organism assemblages via brine instability and nutrient transport. The results suggest that, during a mild winter, Baltic sea ice is a highly dynamic environment, in which interactions between the physical, chemical and biological properties of the ice determine the succession of ice-organism assemblages and the functioning of the ice microbial food-web. In the current study, an overview of these interactions has been given. For a more detailed picture of the microbial food-web dynamics of Baltic sea ice, experimental and higher-resolution, explorative studies focused on specific food-web components and their interactions are still needed.

Acknowledgements. Many people are acknowledged for their assistance and help during this work; I. Lastumäki and A. M. Åström for nutrient analyzes, J. Räty and K. Kivi for help in microscopy. M. Granskog and J. Ehn for assistance in the field. Constructive comments of H. Kuosa, R. Autio and K. Kivi greatly improved the manuscript. The access to the facilities of the Tvärminne Zoological station and continuous support of the station's staff are also gratefully acknowledged. This work was financially supported by the Walter and Andrée de Nottbeck Foundation and the Finnish Institute of Marine Research.

\section{LITERATURE CITED}

Assur A (1958) Composition of sea ice and its tensile strength. Publ Natl Res Counc Can 598:106-138

Bjørnsen KB, Kuparinen J (1991) Determination of bacterioplankton biomass, net production and growth efficiency in the Southern Ocean. Mar Ecol Prog Ser 71:185-194

Cota GF, Legendre L, Gosselin M, Ingram RG (1991) Ecology of bottom ice algae. I. Environmental controls and variability. J Mar Syst 2:257-277

Delille D, Fiala M, Kuparinen J, Kuosa H, Plessis C (2002)
Seasonal changes in microbial biomass in the first-year ice of the Terre Adelié area (Antarctica). Aquat Microb Ecol 28:257-256

Dieckmann GS, Lange MA, Ackley SF, Jennings JC (1991) The nutrient status in sea ice of the Weddell Sea during winter: effects of sea ice texture and algae. Polar Biol 11:449-456

Dolan JR, Gallegos CC (1992) Trophic role of planktonic rotifers in the Rhode River Estuary, spring-summer 1991. Mar Ecol Prog Ser 85:187-199

Fritsen CH, Lytle VI, Ackley SF, Sullivan CW (1994) Autumn bloom of Antarctic pack-ice algae. Science 266: 782-784

Garrison DL, Buck KR (1986) Organism losses during ice melting: a serious bias in sea ice community studies. Polar Biol 6:237-239

Golden KM, Ackley SF, Lytle VI (1998) The percolation phase transition in sea ice. Science 282:2238-2241

Gradinger R, Zhang Q (1997) Vertical distribution of bacteria in Arctic sea ice from the Barents and Laptev Seas. Polar Biol 17:448-454

Gradinger R, Spindler M, Weissenberger J (1992) On the structure and development of Arctic pack ice communities in Fram Strait: a multivariate approach. Polar Biol 12: 727-733

Granskog MA, Kaartokallio H, Shirasawa K (2003) Nutrient status of the Baltic Sea ice-evidence for control by snowice formation, ice permeability and ice algae. J Geophys Res 108(C8), 3253, doi: 10.1029/2002JC001386

Grasshoff K, Ehrhardt M, Kremling K (1983) Methods of seawater analysis, 2nd edn. Verlag Chemie, Weinheim

Grossmann S, Dieckmann GS (1994) Bacterial standing stock, activity and carbon production during formation and growth of sea ice in the Weddell Sea, Antarctica. Appl Environ Microbiol 60:2746-2753

Guglielmo L, Carrada GC, Catalano G, Dell'Anno A and 5 others (2000) Structural and functional properties of sympagic communities in the annual sea ice at Terra Nova Bay (Ross Sea, Antarctica). Polar Biol 23:137-146

Haecky P, Andersson A (1999) Primary and bacterial production in sea ice in the northern Baltic Sea. Aquat Microb Ecol 20:107-118

Haecky P, Jonsson S, Andersson A (1998) Influence of sea ice on the composition of the spring phytoplankton bloom in the northern Baltic Sea. Polar Biol 20:1-8

HELCOM Baltic Marine Environment Protection Commission-Helsinki Commission (1988) Guidelines for the Baltic Monitoring Programme for the Third Stage; Part D. Biological determinants. Baltic Sea Environment Proceedings 27D, p 16-23

Helmke E, Weyland H (1995) Bacteria in sea ice and underlying water of the eastern Weddell Sea in midwinter. Mar Ecol Prog Ser 117:269-287

Hudier E, Ingram G (1994) Small scale melt processes governing the flushing of nutrients from a first-year sea ice, Hudson Bay, Canada. Oceanol Acta 17:397-403

Ikävalko J, Thomsen HA (1997) The Baltic Sea ice biota (March 1994): a study of the protistan community. Eur J Protistol 33:229-243

Kaartokallio H (2001) Evidence for active microbial nitrogen transformations in sea ice (Gulf of Bothnia, Baltic Sea) in midwinter. Polar Biol 24:21-28

Kirchman D, K'Nees E, Hodson R (1985) Leucine incorporation and its potential as a measure of protein synthesis by bacteria in natural aquatic systems. Appl Environ Microbiol 49:599-607

Kivi K, Setälä O (1995) Simultaneous measurement of food particle selection and clearance rates of planktonic oligo- 
trich ciliates (Ciliophora: Oligotrichina). Mar Ecol Prog Ser 119:125-137

Krembs C, Gradinger R, Spindler M (2000) Implications of brine channel geometry and surface area for the interaction of sympagic organisms in Arctic sea ice. J Exp Mar Biol Ecol 243:55-80

Krembs C, Mock T, Gradinger R (2001) A mesocosm study of physical-biological interactions in artificial sea ice: effects of brine channel surface evolution and brine movement on algal biomass. Polar Biol 24:356-364

Kuuppo P (1994) Annual variation in the abundance and size of heterotrophic nanoflagellates on the SW coast of Finland, the Baltic Sea. J Plankton Res 16:1525-1542

Laurion I, Demers S, Vézina AF (1995) The microbial food web associated with the ice algal assemblage: biomass and bacterivory of nanoflagellate protozoans in Resolute Passage (High Canadian Arctic). Mar Ecol Prog Ser 120:77-87

Leppäranta M, Tikkanen M, Shemeikka P (1998) Observations of ice and its sediments on the Baltic Sea coast. Nord Hydrol 29:199-220 'Nordic Hydrology' after ISDS

Mälkki P, Tamsalu R (1985) Physical features of the Baltic Sea. Finn Mar Res 252:23-27

Maranger R, Bird DF, Juniper SK (1994) Viral and bacterial dynamics in Arctic sea ice during the spring algal bloom near Resolute, N.W.T., Canada. Mar Ecol Prog Ser 111: 121-127

Massana R, Gasol JM, Bjørnsen PK, Blackburn NT and 5 others (1997) Measurement of bacterial size via image analysis of epifluorescence preparations: description of an inexpensive system and solutions to some of the most common problems. Sci Mar 61:397-407

Meiners K, Fehling J, Granskog MA, Spindler M (2002) Abundance, biomass and composition of biota in Baltic sea ice and underlying water (March 2000). Polar Biol 25: 761-770

Mock T, Meiners K, Giesenhagen H (1997) Bacteria in sea ice and underlying brackish water at $54^{\circ} 26^{\prime} 50^{\prime \prime} \mathrm{N}$ (Baltic Sea, Kiel Bight). Mar Ecol Prog Ser 158:23-40

Editorial responsibility: Evelyn and Barry Sherr (Contributing Editors), Corvallis, Oregon, USA
Norrman B, Andersson A (1994) Development of ice biota in a temperate sea area (Gulf of Bothnia). Polar Biol 14: 531-537

Pelegri SP, Dolan J, Rassoulzadegan F (1999) Use of high temperature catalytic oxidation (HTCO) to measure carbon content of microorganisms. Aquat Microb Ecol 16: $273-280$

Sherr EB (1988) Direct use of high molecular weight polysaccharide by heterotrophic flagellates. Nature 335: $710-711$

Sime-Ngando T, Gosselin M, Juniper KS, Levasseur M (1997) Changes in phagotrophic microprotists $(20-200 \mu \mathrm{m})$ during the spring algal bloom, Canadian Arctic Archipelago. J Mar Syst 11:163-172

Smith REH, Gosselin M, Kudoh S, Robineau B, Taguchi S (1997) DOC and its relationship to algae in bottom ice communities. J Mar Syst 11:71-80

Spindler M (1994) Notes on the biology of sea ice in the Arctic and Antarctic. Polar Biol 14:319-324

Stoecker D, Buck KR, Putt M (1993) Changes in the sea-ice brine community during the spring-summer transition, McMurdo Sound, Antarctica. II. Phagotrophic protists. Mar Ecol Prog Ser 95:103-113

Thomas DN, Papadimitriou S (2003) Biogeochemistry of sea ice. In: Thomas DN, Dieckmann GS (eds) Sea ice: an introduction to its physics, chemistry, biology and geology. Blackwell Science, Oxford, p 267-302

Thomas DN, Lara RJ, Eicken H, Kattner G, Skoog A (1995) Dissolved organic matter in Arctic multi-year sea ice during winter: major components and relationship to ice characteristics. Polar Biol 15:477-483

Utermöhl H (1958) Zur Vervollkommnung der quantitativen Phytoplankton-Methodik. Mitt Int Ver Theor Angew Limnol 9:1-38

Vezina AF, Demers S, Laurion I, Sime-Ngando T, Juniper KS Devine L (1997) Carbon flows through the microbial food web of the first-year ice in Resolute Passage (Canadian High Arctic). J Mar Syst 11:173-189

Submitted: June 12, 2003; Accepted: December 8, 2003 Proofs received from author(s): May 28, 2004 